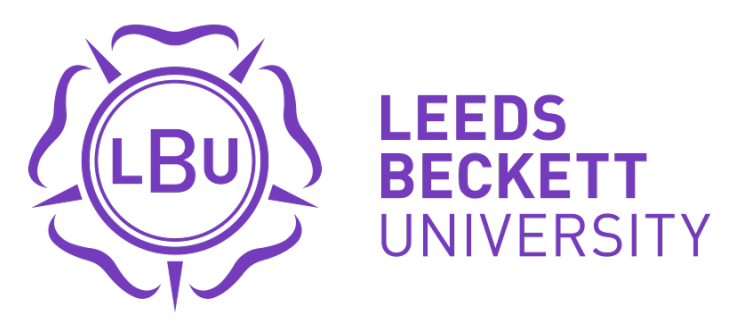

Citation:

Gardiner, S. and Parry, J and Robinson, SJ (2016) "Integrity and the corruption debate in sport: where is the integrity? European Sport Management Quarterly, 17 (1). ISSN 1618-4742 DOI: https://doi.org/10.1080/16184742.2016.1259246

Link to Leeds Beckett Repository record:

https://eprints.leedsbeckett.ac.uk/id/eprint/3573/

Document Version:

Article (Accepted Version)

The aim of the Leeds Beckett Repository is to provide open access to our research, as required by funder policies and permitted by publishers and copyright law.

The Leeds Beckett repository holds a wide range of publications, each of which has been checked for copyright and the relevant embargo period has been applied by the Research Services team.

We operate on a standard take-down policy. If you are the author or publisher of an output and you would like it removed from the repository, please contact us and we will investigate on a case-by-case basis.

Each thesis in the repository has been cleared where necessary by the author for third party copyright. If you would like a thesis to be removed from the repository or believe there is an issue with copyright, please contact us on openaccess@leedsbeckett.ac.uk and we will investigate on a case-by-case basis. 


\title{
INTEGRITY AND THE CORRUPTION DEBATE IN SPORT: WHERE IS THE INTEGRITY?
}

\author{
Simon Gardiner a, Jim Parry b and Simon Robinson a \\ (a Centre for Governance, Leadership and Global Responsibility, Leeds \\ Beckett University; b Charles University in Prague)
}

\section{ABSTRACT TO ADD}

Keywords: integrity; corruption; value;

\section{Introduction}

A series of high profile cases focused on extreme forms of gamesmanship, doping or financial impropriety, have recently reignited the debate about integrity in sport, not least in cricket, football, tennis and cycling. This article argues that there are different views of integrity at play in the debate, focusing on sport itself but also on the governance of sport. It argues for a development of the concept of integrity, such that the many different stakeholders involved in the management of sport can develop more effective dialogue, engaging both the concept and practice of integrity and effective regulation.

The use of the term 'integrity' has in recent years become common currency in the sports world. It seems to represent a central standard that sporting participants concerning a range of competition governance issues and sporting administration need to coalesce around. However, the ubiquitous use of the term has resulted in its exhibiting both imprecision and superficiality. Different actors within and without the sports industry use the term 'integrity of sport' in different ways. Sometimes it means simply 'honesty', and sometimes it is used as a catch-all phrase for an amalgam of a range of sports-related values including unpredictability of outcome and a promotion of a level playing field. Sometimes it is used as a counter-factual, to describe desirable outcomes, such as non-corrupt administration, or non-fixed matches. We shall argue for a wide view of integrity, that distinguishes between forms of personal, sporting, organisational and commercial integrity, whilst indicating a core meaning of the concept, common to all those forms.

The first part of the article will examine the emergence of a plethora of sporting and non-sporting bodies and actors promoting an ideal of sporting integrity in recent years - these bodies comprise what can be termed the 'sports integrity industry'. The second part of the article will clear the 
conceptual ground, examining various philosophical and psychological views of integrity. This analysis will primarily focus on organisational integrity, initially distinguishing moral and behavioural integrity. The first of these will focus on integrity as: congruence of moral purpose and practice; the focus of moral identity; a single virtue or collection of virtues. It will argue that all three play some part in an understanding of moral integrity, but that the concept needs to be developed in the light of the complex social environment exemplified in the governance of sport. This requires greater attention: to underlying meaning and worth; to critical and transparent dialogue as a key aspect of integrity; to the relationship of responsibility to integrity - including agency, accountability, and liability; and inter-organizational integrity and governance. The authors will argue that these form part of the integrative nature of integrity.

The recent literature on management and leadership has sought to distinguish behavioural integrity from moral integrity, focusing on consistency rather than value, and the role this has in creating trust. This article will critique this view, arguing against a value-neutral concept. It will argue rather that moral and psychological values are key to relationships inside and outside the organisation, and that dialogical identity which addresses these is more important for their development. In a range of sports organisations, and probably most evidently at the international sports federation level, with the Union Cycliste Internationale (UCI), the International Association of Athletics Federations (IAAF) and the Fédération Internationale de Football Association (FIFA) obvious exemplars, a valuebased notion of integrity has largely been absent.

\section{The Policing of Integrity}

The first part of the paper will examine the ways in which integrity in sport has been approached in recent years by a range of organisational actors. It is not an exclusive listing but a brief examination of the most prominent bodies and their usage and understanding of integrity. These bodies, representing the different stakeholders in sport, can be termed the 'sports integrity industry'.

\section{Within the Sports Industry}

A development over the last fifteen years or so is that major International Sports Federations have developed or partnered with monitoring and compliance bodies. These include the International Cricket Council's (ICC) 'Anti-Corruption and Security Unit'; the Union of European Football Association's (UEFA) 'Early Warning System' managed by the commercial company Sportradar; and the International Tennis Federation's (ITF) 'Tennis Integrity Unit'. In national sport, an example 
would be the English Football Association and the Premier League who, together with Major League Baseball, work with the commercial company, Sport Integrity Monitor (SportIM). All of these bodies, and those in other sports, talk about upholding integrity but very few provide any real articulation of their meaning of the term beyond a need to engage with competition governance issues such as match fixing and anti-doping. The ITF body in tennis has integrity in its title but provides no meaning of the term, although the Report that led to its creation indicated that 'integrity in sport is crucial to its success and to the enjoyment of participants, spectators and other interested stakeholders' (ITF, 2008). Indeed, as a body, the focus is primarily and narrowly on match fixing.

This focus on connecting integrity primarily to financial corruption, match fixing and betting, can be found with the International Olympic Committee's 'First International Forum for Sports Integrity' (a new name for the already existing 'Founding Working Group on the Fight Against Irregular and Illegal Betting in Sport'). Launched in 2015, it has 'an objective to adopt a roadmap for future action to protect clean athletes' (IOC, 2015). But, again, there is a paucity of meaningful discussion on a wider understanding of integrity. A welcome attempt to provide a more meaningful analysis of integrity is found in a recent SportAccord initiative, where the complexity and multiplicity of its constituent elements is highlighted. However, the definition offered suggests ways in which integrity might be displayed, rather than saying what integrity is:

Integrity in sport is displayed through quality leadership practices that embrace the spirit and purity of sport, transparent governance structures that strengthen public trust and belief systems that create ethical, moral and value laden decision-making processes that sustain sport from community to elite levels in creating a better society (Gilbert and Skinner, 2015).

As a final example, the World Anti-Doping Agency (WADA), which has taken the lead role in antidoping for more than fifteen years, states that it views integrity as one of its core values, in seeking to 'develop policies, procedures that reflect justice, equity and equality' (www.wada.org). Perhaps not surprisingly, there are ambitions in WADA to expand into a wider remit beyond anti-doping and to assume the role of 'World Sports Integrity Agency' (Howman, 2015). What is surprising in this context is that WADA appears not to have engaged in a rigorous scrutiny of the definitional complexities around integrity.

\section{The Gambling Industry}


Highlighting the complex interaction between the modern sports industry and the gambling and betting industry, industry trade bodies representing the betting industry have emerged, such as the European Sports Security Association (ESSA). Despite a stated focus on 'Sport Betting Integrity' and the organisation's core mandate, 'to facilitate cross-sector partnerships and to protect operators, their customers and sporting bodies from betting related corruption', there is no wider discussion of the term. Similarly, European Lotteries (EL) represents state-owned and private operators of national lotteries around Europe.

\section{Law enforcement agencies}

National, supra-national and international agencies have become actively involved in engaging with illegality around sports related betting and match fixing. For example, the UK's Sports Betting Integrity Unit (SBIU) of the Gambling Commission, a statutory governmental body, has a stated aim of bringing 'together the intelligence efforts of partners and play its part in protecting sport from corruption in support of the Sports Betting Integrity Action Plan' (SBIU, ****). Interpol's 'Integrity in Sport' programme is a global training, education and prevention initiative with a focus on matchfixing as well as irregular and illegal betting. Its two main aims are, firstly, to educate and train key actors in sport on how to recognize, resist and report attempts to corrupt or fix matches, and secondly, to better prepare law enforcement on how to investigate and cooperate in corruption or match-fixing related cases. Both bodies highlight education, awareness and a multi-agency approach to financial corruption but say little more on a wider meaning of integrity.

\section{Pan-European governmental bodies}

Both the European Union (EU) and the Council of Europe (COE) are engaging with corruption in sport. A significant development is the COE's recent promulgation of the 'Convention on the Manipulation of Sports Competition'. The Convention's purpose is 'to combat the manipulation of sports competitions in order to protect the integrity of sport and sports ethics in accordance with the principle of the autonomy of sport' (COE, 2014). This is an important development in the engagement with financial manipulation of sport creating certain legal obligations on signatory States. Interestingly in Article 3 of Convention however, integrity is not defined, although many other terms are.

\section{Sports Development Bodies}

A number of national sports development bodies have focused on integrity issues in sport. Perhaps the most extensive analysis of integrity and the wider ethics of sport has been carried out by the 
Australian Sports Commission (ASC). In the ASC's 'Integrity in Sport Literature Review', in 2011, the main findings were: integrity is a complex term that takes on different meanings in different environments and contexts; integrity requires respect for oneself and for others; integrity requires moral responsibility and moral accountability; sport, as a whole, can be both inimical and favourable to integrity. A lengthy extract is instructive,

Integrity is the integration of outward actions and inner values. A person with integrity does what they say they will do in accordance with their values, beliefs and principles. A person of integrity can be trusted because he or she never veers from inner values, even when it might be expeditious to do so. A key to integrity, therefore, is consistency of actions that are viewed as honest and truthful to inner values ... A sport that displays integrity can often be recognized as honest and genuine in its dealings, championing good sportsmanship, providing safe, fair and inclusive environments for all involved. It will be also expected to 'play by the rules' that are defined by its code. A sport that generally displays integrity has a level of community confidence, trust and support behind them. The impact of this on their business cannot be underestimated' (Treagus, Cover and Beasley, 2011).

So, Integrity in Sport is seen as having many positive benefits on and off the field of play. Activities and behaviours that define sport as lacking integrity include: creating an unfair advantage or the manipulation of results through performance enhancing drugs, match fixing or tanking, and extending to anti-social behaviours demonstrated by parents, spectators, coaches and players including bullying, harassment, discrimination and child abuse.

What is worthy of note is that a number of new players have emerged professing expertise together with recognising commercial opportunities. Prominent in this regard is the International Centre for Sports Security (ICSS) with a stated focus on 'Integrity, Transparency and Anti-Corruption' (ICSS). Although holding itself out as a non-governmental organisation, it appears to be largely state-funded by the Qatari government. Putting aside concerns around issues such as the circumstances of how Qatar secured the 2022 FIFA World Cup (Gibson, 2015), deplorable labour conditions for immigrant workers infringing international labour law and human rights provisions (Amnesty International, 2014), and suspicions that the Qatari Government is implicated in indirectly funding the so-called Islamic State (Taylor, 2014), the legitimacy of this organisation in the world of sport is in need of review. The ICSS rhetoric nonetheless is robust and ambitious, identifying itself as 'a globallyrenowned and respected leader in sport safety, security and integrity ... the ICSS is a well-regarded and leading voice in the fight to protect the integrity of sport' (ICSS). The organization does not appear to have any real analysis of the meaning of integrity (also see Sorbonne-ICSS, 2014). 


\section{Non-Governmental Bodies}

Other important organisations in the area, which either have arms-length connection to government or real independence include, 'Play the Game' and 'Transparency International'. Both provide an external voice and dialogue around integrity issues in sport, the former questioning the discourse within sport, the latter providing insight from a range of other spheres of activity. However neither appear to provide an extended examination of integrity in conceptual terms. There is also a plethora of organisations that offer consultancy services, including for e.g. in the UK alone, Sporting Integrity (www.sportingintegrity.com/3.html) and the Sports Integrity Initiative (www.sportsintegrityinitiative.com). Additionally, single issue projects have emerged from some organisations, such as 'New Fifa Now' (www.newfifanow.org), with its focus on the reform of FIFA,

This brief review of a fast growing 'sports integrity industry' reveals: different narratives about integrity amongst the different groups; a lack of integration between the different views of integrity in sport; and the danger of imposing a corporate model of (behavioural-based) integrity. This article argues that, as far as effective engagement with corruption goes, sport needs to look beyond its own experience and to take cognisance of the wider debate concerning integrity and governance.

\section{CONCEPTUAL CLARITY}

First, given the great value that is placed on integrity it is perhaps surprising that a systematic focus on integrity does not appear in either Aristotle or the Judeo-Christian tradition (Cottingham 2009). Later virtue ethicists (Solomon 1982, Wolf 2009) do aim to include it, focusing on integrity as expressed in Aristotle's idea of the unity of the virtues. In this Aristotle argues that the virtues are interconnected, and that a person who practices one will have them all (see Cottingham 2009). Prior to Aristotle, Plato focuses onthe idea of one virtue with different aspects (Wolf 2009). This sense of unity suggests something of the core meaning of integer or integras as soundness, purity or wholeness (Bosman 2012) with the corresponding meaning of corruption as breaking down, spoil or decay (Ibid.). This suggests related indicators of integrity such honesty, transparency, consistency and so on (Cottingham 2009). 
Subsequent discussions in philosophy are summed by the Institute of Chartered Accounts in England and Wales report on professional integrity (ICAEW 2009). This argues for the utility of integrity, as enabling trust, in leadership,the profession and the wider finance industry (cf. Solomon 2007, Armstrong et al 1999). Four different major philosophical approaches to integrity are reviewed (cf. also Scherkoske 2013, and Palanski and Yammarino 2007): self-integration; identity; moral purpose; and commitment.

Self-integration. This account of integrity suggests the integration of what Frankfurt (1961) refers to as higher order or lower order volitions. Higher order volitions involve long term desires, and lower order volitions immediate desires. The higher order volition of the drug addict, for instance, may be to be a drug free person and the lower order volition to take drugs. Integrity, and with that free will, argues Frankfurt, is achieved when the lower order volitions cohere with the higher order volitions, bringing together volition and action. Self-integration can also been seen in terms of developing a holistic integration of the self that brings together the cognitive, affective and somatic aspects of the person(Solomon 2007).

Identity.

Williams (1973) argues for a view of integrity based in the identity of the person. This is part of his argument against a simple utilitarian approach. One example that he offers is of a dignitary who is the guest of a foreign nation. He is taken to a town square where 20 people are about to be killed as reprisals for recent armed protests. As a significant guest the visitor is offered the opportunity to kill one of the 20, thus allowing the other 19 to live. A utilitarian response might support this based on the saving of 19 lives. In arguing against this Williams argues that such a calculation is inadequate because it involves going against the core moral beliefs that make up the identity of the person.

However, neither self-integration nor identity can be sufficient for a view of integrity, since the moral framework of either may be flawed or questionable. The SS guard may both all these things (including a strongly held world view - cp. Burleigh 2011, Cottingham 2010). In a story such as In Bruges (2008, Universal) the criminal head is an ambiguous character precisely because he reveals a 
strong version of this kind of integrity, which in one sense is admirable, but which is displayed in the context of a business focused in murder. Precisely because of this other philosophers argue that integrity must relate more clearly to accepted wider ethical norms

Moral purpose.

Rawls (1972) and Halfon (1989) argue that integrity must include an acceptable moral purpose at the base. For Rawls this would involve some clear conception of justice, defined in terms of fairness. Halfon is more circumspect, arguing that integrity involves setting out an ethical perspective that is conceptually clear, logically consistent, apprised of relevant empirical evidence, and careful about acknowledging as well as weighing relevant moral considerations. In effect, Halfon argues that the person of integrity will give a clear account of their moral purpose as part of following a rigorous moral decision making process.

\section{Commitment.}

Calhoun (1995) argues for a sense of commitment which is about 'standing for something.' She argues that this involves more than simply standing for an individual moral purpose, but rather for a purpose recognised by some community, which affords the basis for integrity. Integrity here is associated explicitly with something worth striving for, and it assumes a degree of agency, courage and perseverance that will enable the person or group to standup against internal and societal pressures that impose obstacles to the purpose. The concern for the practice of rational agency, for taking responsibility for holding certain values, is echoed by Mason (2001) He argues for the importance of respect for human dignity as a core community principle. In all this integrity becomes more a social value than an individual one. This, however, raises critical questions about the nature of social relations. Before turning to that, it is important to note some attempts in business studies, especially in leadership and economics, to bypass this debate about the meaning of integrity through distinguishing moral and behavioural integrity.

\section{Moral and behavioural integrity}


The attempt to distinguish moral and behavioural integrity can be seen both as a response to the limitations of the first two views above and also an attempt to have a view of integrity which is straightforward for business practice. Moral integrity Simons argues is seen in terms of the leader remaining true to principles (Simons 1999). Hence, this is subject to the problem of which principles and who decides which ones to follow. Behavioural integrity is focused leadership practice and above all the need of the leader to generate trust. Trust, it is argued, is enabled through consistency of leadership behaviour, focused in the purpose and values of the organisation, and the research task becomes the exploration of the connection between trust and integrity in this sense. However, as Bauman (2013) notes, whilst it is clearly possible to conceptually distinguish moral and behavioural integrity, in practice, the two are connected. Bauman (2013) argues that are three kinds of integrity focused in leadership, which are not exclusive and which contribute to 'conferring' identity on leadership: substantive, formal, and personal. Substantive leadership integrity is based in the core moral values (defined by Bauman in relation to transformational leadership). In effect this is moral integrity. Formal leadership integrity is focused on fulfilling values without question. Personal leadership integrity gives priority to personal as distinct from moral values. Even such personal values, however, are perceived as connecting to moral values. Others, such as economists Erhard and Jensen (2014)argue that integrity is distinct from the domains of ethics, morality and the law. They define it in terms of wholeness, arguing that this is critical to the success of any business project, and that is can be seen as positive, i.e. scientific as distinct from normative. However, Erhard and Jensen use concepts, such as honouring ones word, which are themselves values laden suggesting that integrity cannot be simply preformative and is focused in purpose and commitment.

If we turn again to the integrity of the SS guard, the stress on moral purpose and commitment would suggest two key challenges that he could not meet. The first involves the capacity to question different values critically, including the core values of his group and leadership. Without that capacity it is difficult for the person to appreciate, (i.e. to understand the meaning and worth of) the values in question. This is central to Zygmunt Bauman's view of responsibility (1989, cf. Levinas 
1989). Bauman notes the need to engage difference critically (conceptually and affectively). Without that there is the danger of totalization (Bauman 1989), involving individuals or groups not being able to perceive the significance of what they are doing in practice, and with an inability to learn about themselves or the surrounding social context. The second demands a normative stance, recognising that some things are wrong in themselves - pointing to core values which apply beyond those of the group, such as respect for human dignity. Such normative values are focused in both the equality and particularity of the other.

The psychology of integrity

These two poles point to a powerful tension at the heart of integrity - something which in personal terms is reinforced by the psychology of integrity. Polonius's advice to his son is often seen as the basis of a psychology of integrity (cf. Schlegel et al 2009)),

'This above all: to thine own self be true, And it must follow, as the night the day, Thou canst not then be false to any man' (Hamlet 1, 3, 78-80).

Shakespeare, however, does not offer this as a serious view of the self, but rather as humorous counterpoint to the central issue of the play itself, the idea that the self is not fixed, a discrete entity that one is truthful to, but is the product a dialogue between very different narratives ${ }^{1}$. Hence, Hamlet spends the play working through different views of honour and relationships. It is precisely the dialogue and decision making which themselves constitute identity (Greenblatt 2005, Burkitt 2008, Taylor 1989, Cottingham 2009).

Post-modern theory suggest that there is no simple sense of the self, but rather that there are very different narratives which constitute the self (Burkitt, 2010, Cooper-White 2007). Integrity is not then about wholeness as homogeneity, with everything fitting together, but about an honest and open engagement with the different narratives, subjecting them to critical challenge. The different narratives are related to different formative relationships, which also have to be engaged with respect. In this light, integrity involves hard work and even suffering (Cottingham 2010, Pianalto

\footnotetext{
${ }^{1}$ Hence Polonius's advice comes at the end of a long list of shallow aphorisms.
} 
2012) and involves recognition of contradictions and inconsistencies in the self. Often psychological pathology emerges precisely when narratives, for whatever reason, are suppressed or ignored (Cooper White 2007). All of this has discernible effect on how the person views him or herself and the world. It is not surprising then that unresolved psychological problems might reinforce any 'blindness' in this. Jung views such blindness in terms of a shadow side (Cottingham 2009, Fawkes 2014). This is not a 'dark' side but rather the part of our behaviour or thinking we have not examined. Fawkes argues that this applies equally to professional and business ethics. Pattison and Edgar (2011), writing about the profession of nursing, suggest that claims of integrity are often based in such blindness about the self or the organization. They suggest that some whistle-blowers exhibit this narrow form of integrity. It is characterised by defensive behaviour where integrity is interpreted in terms of defending ideologies, organisations or others. In individual and organizational terms this blindness may be based in the identity of the person or group. Hence, Greenpeace felt they were acting with integrity in boarding the Brent Spar Oil Platform (Entine 2002), only later accepting that their ideology, and related identity as defenders of the environment, blinded them to the actual data about the rig. Nonetheless, true to their perceived identity, they argued they would still do the same thing. Heffernan (2011) notes that, in any case, there are psychological and physical limitations which make it difficult for persons and organizations to see themselves accurately. Hence, integrity demands acknowledgment of such limitations and requires the perspective of others. This is precisely why corporate governance codes include the requirement for non-executive directors, to bring an external perspective (cf. King III). Integrity and dialogue

All this suggests a more dynamic view of integrity which is focused in dialogue, both critical and holistic, with different narratives and related narrators and involving ongoing reflection on and learning about identity and thus relationships to the social environment. As we suggest above, this applies to both personal and organizational integrity. Just as the person may be said to be plural the organization, institution or corporation may be said to be plural. Good examples of this are 
professional institutions. These relate to the different narratives, of clients, members, corporations or other organisations which members work in, other professions who may share a wider purpose, future generations (through the different creations, from bridges to healthcare facilities). They also relate to wider society both through the pre-moral or moral good which form their key purpose and thus identity (Airaksinen 1994), such as health and well-being for the medical profession or justice for the legal professions. The identity of the profession is thus a function both of moral underpinning and of ongoing dialogue in the different relationships. This view of professional integrity becomes even more complex in specific areas such as health care. In the recent case of the Mid Staffs Hospital Trust (Francis Report 2013) the integrity of this healthcare project required dialogue with many different organisations and professions who were involved, including concern about the sustainability of the Trust itself. In effect this involved the need for a complex interinstitutional integrity. Instead the focus was centred on organisational sustainability, with a narrow view of accountability which led to an exclusive narrative and a culture of fear.

The same picture of plural narratives can be seen in organizations such as corporations (Robinson 2009). Far from having a single identity the corporation relates to different professions, some part of all corporations, such as accountancy and human relations, some related to the nature of the corporation, such as engineering. Many corporations are also related to wider industries, some of which, as noted above by the ICAEW report (2009), form the basis of trust in essential social and economic activities. Brown (2005) develops this theme for corporations, noting five dimensions of corporate integrity - cultural, interpersonal, organizational, social and natural. The first focuses on difference and disagreement in meaning, the second integration and wholeness, the third core purpose, the fourth on civic cooperation, and the final on the environment. Integrity in this light demands both commitment to core relationships but also awareness and appreciation of the plurality of relationships that form the social and physical environment. Such relationships are by definition interdependent, and integrity demands a working through of what that requires in practice (Koehn 2005). Organizational integrity in the light of this once more requires both attention 
to internal dialogue but also attention to shared core values, both relational, such as justice, or connected to the nature or purpose of the organization (cf. Khurana and Nohria 2008). The issue of organizational justice relates precisely to procedural integrity. Here procedures need to embody a shared understanding of justice and of the core prupose of the organization.Governance in business often assumes that evidence of process, such as a sub- committee of the board for leader remuneration, is sufficient. However, for the most part this focuses purely on leaders pay, does not give a full account of justice, in this case involving the criteria of distribution, in the firm as a whole, and does not open this to genuine dialogue (Kolb 2005).

Such adynamic view of integrity connects different integrities which are often seen as discrete. For instance, whilst personal integrity can be distinguished from moral, the two are connected precisely because they are both part of the person's identity. Godlovitch (1993), in another example, argues that professional integrity is different from and weaker than moral integrity, and isanalogous to etiquette. In contrast (Ibid. 573), integrity 'trades between the norms of unity and honesty'. However, once more, it difficult to see how professional integrity is not directly connected to both personal and moral integrity. Personal integrity is focused in the agency and identity of the person and professional institution and related values are part of the social identity of the person (Burkitt 2009). Similarly, professional integrity is directly linked to moral integrity, partly because professional identity is focused in moral and pre moral goods, and partly because it requires dialogue with those involved in the different relationships. Kekes (1983) suggests that intellectual integrity is distinct from moral integrity. However, it is difficult to see intellectual integrity as unconnected to either practice (cf. Aristotle's intellectual virtues), and therefore to communities of practice which involve relationships and to core relational values such as justice, or to moral integrity. Aristotle's phronesis is precisely an intellectual virtue which is critical to the practice of moral virtues (see also Solomon 2007 on the intellect and affective dimensions). 
The problem with the views which try to see the different integrities as discrete is that they are based on the assumption that the underlying areas are discrete. In arguing for an holistic view of integrity Solomon (2007) precisely notes the connection between the intellect and the affect, the affect and value, and how values and related sense of worth (self and other) relate to identity. As we suggest above this leads to a view of integrity based in on-going reflective dialogue and learning about the self and others (based partly in the challenge of difference) $)^{2}$.

Integrity, responsibility and virtue

Such a dynamic view of integrity develops Calhoun's view of integrity as focused in taking responsibility (cf Robinson 2009). This involves, first, taking responsibility for core values, purpose, sense of worth, and practice and its effect on the social and cultural environment. This is core to personal or organisational identity (Taylor 1989), and thus to autonomous agency. Second, it demands taking responsibility for giving an account of this identity to the self/organization and others, focused in ongoing critical dialogue. Such dialogue enables a continual testing of the shadow side of any organization and further presentation and development of the self/organization identity. Third, it demands a shared responsiblity for maintaining both the representation of core values and purpose and harmony amongst the different narratives, inclduing the sustainability of the self/organization and the core values. Such shared responsibility demands once more ongoing critical dialogue and the negotiation of responsibility, further representing and establishing identity.

\footnotetext{
2 The underlying view of dialogue here is located more in the theory of Bakhtin (1981) than in Habermas (1992). Bakhtin focus on engaging with complexity, whereas Habermas stress order and rationalism.
} 
Curzer (2014) expresses such a dynamic in terms of a virtue. He argues that Aristotle views it as a personal virtue involving representing oneself accurately and reliably to others. The self is seen is seen as one's history, one's current character, and one's future projects) and expressed in one's Commitments (to ideals, values, goals, projects), especially about those that are important to one's Reputation. This is not a meta-virtue, encompassing many other virtues such as honesty, transparency, or authenticity but a discrete virtue focused in being true to the self, one's identity. He notes that the self (2014, p. 271) is not single but made of many different, often conflicting relationships and their value narratives. Hence he argues that integrity does not demand compatability between all these narratives, or an attempt to integrate all of the meanings. Such a truthful representation of personal or organizational identity demands continual critical dialogue.

\section{Integrity and sport}

This core notion can be applied to different aspects of the sports process, enabling us to distinguish several interconnected views of the term integrity, which we may identify as:

- the integrity of sport itself

- personal integrity in sport

- the organisational integrity of sport

- procedural integrity in the sport event

First, and fundamentally, is the integrity of sport itself, focused in an identity maintained by a cooperative community that recognizes and respects the goods and excellences that are internal to the activity, and the core values that define it, including justice (as fairness), respect (inclusivity and 
care), excellence, and competition. This identity, however, is always contested, not least because the different values, and related narratives, are always potentially conflictual.

Simon argues that competitive sport is defined as a mutually acceptable quest for excellence through challenge. This mutuality implies duties to foster a context of competition, which basically obliges contestants to maintain and promote the internal goods and standards of excellences of sport. Moreover, this mutuality is based on considerations of moral equality - namely, that participants are entitled to equal concern and respect. Integrity in sport is how these aspects of the sport 'self' are held together and re-presented.

Second, then, we can distinguish personal integrity in sport, in which the individual sportsperson, be they contestant, administrator, referee and so on, takes responsibility for representing this identity in their practice.. The personal integrity of a sportsperson lies centrally in her ability to sustain her reputation by accurately and reliably representing her identity as she strives to meet her commitments. Doping, match-fixing, or any other form of cheating, all rely on various forms of deception, which necessarily involves misrepresenting one's identity and values. These are classic cases of lack of integrity which, when discovered, inevitably lead to a loss of reputation. Of course, this is tightly connected to professional integrity.

Third, we can distinguish another form of integrity in sport focused in the organisation or institution. For our purposes, an organisation is perhaps best seen as a collective person, and so the integrity of a sport organisation can be seen to lie centrally in its ability to sustain its reputation by accurately and reliably representing the identity and values of the organization as it moves forward towards meeting its commitments. However, a key further commitment at this point is expressed in value of sustainability, that is, of the organisation. This may be the organisation of a particular sporting club or team, or the administration of a sport (e.g. FIFA). According to Alasdair Maclntyre (1981), institutional organizations are required to sustain the social practices of which they are the 
bearers - since no practice can survive any length of time unsustained by some institution. However, Maclntyre warns that, because of their concern with external goods (those, such as money and power, that are only contingently connected with social practices), institutions might have a corrupting influence on the social practices they are supposed to protect and advance. To avoid such corrupting influence, as Mike McNamee argues (ref?), sport institutions should ensure that their primary commitment is to sport's internal goods and standards of excellence. The point is not to deny the role of external goods in social practices but rather to subordinate them to the central purpose of competitive sport and the moral principles that competitive sport demands. That is, external goods should be kept in their place. This should be understood as the organisational integrity of sport.

Once again, such integrity is never monophonic, not least because alongside the core sporting identity, any organisation, qua organisation, is situated in local, regional or global contexts where it has significant relationships, with related narratives. A football club may be an important part of the local economy. A sporting body may make significant contributions to the social inequality across the world. At the same time the sporting organisation may develop partnerships with firms who themselves, through supply chains and so on, relate to different contexts, with different expressed values. Hence, integrity demands the practice of continued dialogue, which is focused in core values, critical testing of those values, awareness of the wider relationships and commitments that these involved, linking sport to Brown's (2005) wider view of integrity.

Fourth, it is possible to distinguish the idea of procedural integrity. In one respect this focuses on the logic and value of sport as a social practice with a focus on the integrity of the sporting event. The procedural integrity of sport refers to the trustworthiness of particular sport contests. This dimension involves, firstly, the personal integrity of all those who are directly engaged in contesting (e.g., contestants, coaches, and referees), who should be fully committed to the central 
purpose of competitive sport - the establishment of skillful superiority and the comparison of the relative ability of the contestants - and to doing so respecting considerations of moral equality.

Procedural integrity is also a key aspect of organisational integrity, and thus is key to the governance of both sporting organisations, such as clubs, and to governing bodies of sport. In this context, procedural integrity is itself an expression of organizational integrity, i.e. involving representation of identity (and related values). The danger here is of ill thought through procedures, i.e. ones which do not take responsibility for working through process and core values. Procedural integrity demands an explicit account of how procedure expresses identity and related values, and clear space for dialogue which tests that. This works through to decision making, and related creative action, which connects to identity, and thus to ongoing stakeholder dialogue. Procedures which do not have this level of integrity will lead to blindness, exemplified in the recent FIFA crises.

The crisis of governance in FIFA over the last decade has focused on lack of transparency, corruption and lack of formal governance structures. Perhaps more fundamentally, the governance of FIFA shows a narrow view of integrity which does not connect core values to procedures, has little space for critical deliberation and dialogue, and has thus developed a blindness to the significance of actions both within the organization and beyond (Zeidan and Fauser 2015). 'Integrity', in the first principle of the FIFA Code of Conduct, is not defined. The expression of the term, however, suggests personal integrity. The subsequent ten other principles make mention of core principles, including fairness, and social responsibility eco-sustainability, but there is no attempt to interrogate any of these or begin to see how they connect. Hence, the Code implies a form of total integrity but does not work through the practice, or how that might relate to the specific identity of football in a global context. This has led to discrete narratives around organisational sustainability and global responsibility (not least in terms of aiding football in developing nations), but no significant dialogue between the variety of stakeholders. Inevitably this has led at different points to 'moral blindness', such as initial lack of awareness of the treatment of workers by the Qatari authorities. The 
dominance of the organisational sustainability narrative has been further reinforced by the strong individual leadership focused on Sepp Blatter, and a lack of procedural integrity (what in legal or regulatory terms could be termed a lack of due process), especially around governance structures.

The effect of this has been a lack of responsibility for ideas, values, worth and practice (with global and national arms of FIFA unaware of the wider situation or of their mutual relationships), as accountability (with little distributed leadership or space for mutually challenging dialogue) and as liability (shared responsibility for both global and national values of football and football governance).

\section{Conclusion}

This paper has argued for a core concept of 'integrity' in sport, focussed in taking responsibility for the representation of the 'self' and one's commitments, and a concern for reputation. It also requires effective critical dialogue and deliberation with the different narratives, which constitute the self (individual and organisational), and effective ongoing dialogue around the different values focused in those narratives (hence pointing to more effective stakeholder dialogue which does simply focus on stakeholders needs but also responsibility for values and practice). A distinction has been made between a narrow notion of behavioural integrity and a wider value-based moral integrity. The recent Reports listed above (see Marty et al., 2015; Pound et al., 2016; Schenk, 2011), concerning FIFA, UCl and IAAF respectively, should be congratulated in starting to identify a number of these requirements and expectations. Nevertheless, the prevailing current debate in sport, particularly that promulgated within the 'sports integrity industry', focuses on too narrow and simplistic a view of behavioural integrity that does not make an effective connection to governance. This piece should be seen alongside other recent interventions within the wider sports management literature concerning a more refined understanding of sports integrity (see Cleret, McNamee, \& Page, 2015; Vanden Auweele, Cook, \& Parry, 2016). This nascent body of literature can start to inform the practice of what is admittedly a diverse range of actors attempting to engage with 
integrity issues in sport. We contend that this more complex and dynamic view of integrity will enable the debate to move beyond a Band-Aid response to particular emergencies (such as doping, bribery and match fixing) and towards a more considered and holistic approach to the development of integrity policy

\section{References.}

Airaksinen, T.:1994, 'Service and science in professional life', in R. Chadwick (ed.), Ethics and the Professions (Ashgate, Aldershot) 1-13.

Amnesty international UK. (2015) Promising Little, Delivering Less.

Armstrong, J. Dixon, J and Robinson, S.: 1999, The Decision Makers: Ethics in Engineering (Thomas Telford, London).

Bakhtin , M.: 1981, The Dialogic Imagination: Four Essays (University of Texas, Austin).

Bauman, D.: 2013, 'Leadership and the three faces of integrity', The Leadership Quarterly 24, 414-426.

Bauman, Z.: 1989, Modernity and the Holocaust (Polity, London).

Bosman, P. (2012) Corruption and Integrity: A Survey of the Ancient Terms, in CORRUPTION AND INTEGRITY IN ANCIENT GREECE AND ROME, Acta Classica Supplementum IV Classical Association of South Africa, 1-16.

Brown, M.: 2005, Corporate Integrity (Cambridge University Press, Cambridge).

Burkitt, I. (2008) Social Selves: Theories of Self and Society (Sage, Lomdon) 
Burkitt, I. (2010) 'Dialogues with Self and Others: Communication, Miscommunication and the Dialogical Unconscious', Theory and Psychology, 20(3) 2010, pp.305-321

Calhoun, C.: 1995, 'Standing for Something', Journal of Philosophy XCII, No. 5, May.

Cooper- White, P.: 2007, Many Voices (Fortress, Minneapolis).

Cottingham, J.: 2010, 'Integrity and fragmentation', Journal of Applied Philosophy, 27(1), 2-14.

Curzer, H. (2015) Aristotle and the Virtues (Oxford University Press: Oxford).

Entine, J. (2002) Shell, Greenpeace and Brent Spar: the politics of dialogue, in C.Megone and S. Robinson Case Studies in Business Ethics, 59-95.

Erhard, W and Jensen, M.: 2014, 'Putting Integrity into Finance: A Purely Positive Approach', ECGI Working Paper Series in Finance Working Paper $N^{\circ} .4 / 17$, April.

Fawkes, J.: 2014, Public Relations Ethics and Professionalism: The Shadow of Excellence (Routledge, London).

Finch, J. and Mason, J.: 1993, Negotiating Family Responsibilities (Routledge, London).

Fort, T.: 2007, Business, Integrity, and Peace: Beyond Geopolitical and Disciplinary Boundaries (Cambridge Univeristy Press, Cambridge).

Fort, T.: 2010, 'Peace Through Commerce: A Multisectoral Approach', Journal of Business Ethics , 89:347-350

Francis Report: 2013, The Mid Staffordshire Foundation Trust Public Enquiry, available at http://www.midstaffspublicinquiry.com/ accessed 18/08/14.

Frankfurt, H.: 1971, 'Freedom of the Will and the Concept of a Person', Journal of Philosophy, 68, 520.

Gibson, O. (2015). Russia and Qatar may lose World Cups if evidence of bribery is found. The Guardian, 7 June 2015.

Gilbert, K. \& Skinner, J. (2015) Defining Integrity in Sport. In Sport and Integrity (pp. 17-23). Lausanne: SportAccord.

Godlovitch, S. (1993) 'The Integrity of Musical Performance', Journal of Aesthetics and Art Criticism, 51(4): 573-587.

Habermas, J.: 1992, Moral Consciousness and Communicative Action (Polity, London).

Halfon, M.: 1989, Integrity: A Philosophical Inquiry (Temple University Press,

Philadelphia). 
Heffernan, M. (2011) Wilful Blindness (Simon and Schuster, London).

Howman October 15, 2015 Bookmark and Share Speech by WADA Director General, David Howman, Challenges to the Integrity of Sport, Melbourne

INTERNATIONAL OLYMPIC COMMITTEE PRESS RELEASE, Monday 13 April 2015, www.olympic.org

ITF, 'Environmental Review Of Integrity In Professional Tennis',(2008)

ICAEW: 2009, Reporting With Integrity (ICAEW, London).

Jenkins, D. (1961) Equality and Excellence (SCM, London).

Kekes, J. (1983) 'Constancy and Purity,' Mind, 92: 499-518.

King III (2009), Report on Corporate Governance. Johannesburg: IOD.

Koehn, D.: 2005, Rethinking Feminist Ethics (Routledge, London).

Kolb, R. (ed.) (2005) The Ethics of Executive Compensation (Blackwell, Oxford)

Korsgaard, C.: 2009, Self-Constitution: Agency, Identity, and Integrity (Oxford University Press, Oxford).

Kramer, M. and Porter, M.: 2011, 'Creating Shared Value', Harvard Business Review, JanuaryFebruary, 1-14.

Khurana, R. and Nohria, N. (2008) "It's Time to Make Management a True Profession", Harvard Business Review 86, no. 10 (October 2008).

Lederach, J.P.: 2005, The Moral Imagination (Oxford University Press, Oxford).

Levinas, E.: 1998, Entre Nous: On Thinking-of-the-other (Columbia University Press, New York).

MacIntyre, A. (1981) After Virtue (Duckworth, London).

McFall, L.: 1987, 'Integrity', Ethics 98, 5-20.

Mason, M.: 2011, 'The Ethics of Integrity: Educational Values Beyond Postmodern Ethics', Journal of Philosophy of Education, v. 35 n. 1, 47-69.

Palanski, M. E., \& Yammarino, F. J.: 2007, 'Integrity and leadership: Clearing the conceptual confusion', European Management Journal, 25, 171-184.

Pattison, S. and Edgar, A.: 2011, 'The problem with integrity', Nursing Philosophy, 12: 81-82.

Pianalto, M.: 2012, 'Integrity and struggle', Philosophia, 40:319-336.

Rawls, J.: 1972, A Theory of Justice (Clarendon Press, Oxford).

Riceour, P.: 1992, Oneself as Another (Chicago University Press, Chicago). 
Robinson, S.: 2001, Agape, Ethics and Pastoral Counselling (Aureus, Cardiff).

Robinson, S.: 2008, Spirituality Ethics and Care (Jessica Kingsley, London).

Robinson, S.: 2009, 'The nature of responsibility in a professional setting', Journal of

Business Ethics, 88, 11-19.

Robinson, S.: 2011, Leadership Responsibility (Peter Lang, Oxford).

Robinson, S. and Dowson, P.: 2011, 'Responsibility and integrity in the curriculum', Journal of Global Responsibility, Vol. 2, I: 2, 253-268.

Robinson, S. and Smith, J.: 2014, Co-Charismatic Leadership (Peter Lang, Oxford).

Rodriguez Mosquera, P.: 2013, 'In the name of honor: On virtue, reputation and violence' Group Processes Intergroup Relations , 16: 271

Scherkoske, G.: 2013, Integrity and the Virtues of Reason: Leading a Convincing Life ( Cambridge University Press, Cambridge).

Schlegel, R., Hicks, J., Arndt, J., and King, L.: 2009, 'Thine Own Self: True Self Concept, Accessibility and Meaning in Life', Journal of Personality and Social Psychology, 96, 2, 473-490.

Simons, T. (1999) "Behavioral integrity as a critical ingredient for transformational leadership", Journal of Organizational Change Management, Vol. 12 Iss: 2, pp.89 - 104

Solomon, R.: 1992, Ethics and Excellence (Oxford University Press, Oxford).

Solomon, R.: 2007, True To Our Feelings (Oxford University Press: Oxford).

Sorbonne ICSS Protecting the Integrity of Sport Competition: The Last Bet for Modern Sport (An executive summary of the Integrity Report Sport Integrity Research Programme, 2012-14),

Taylor, C.: 1989, Sources of the Self (Cambridge University Press, Cambridge).

Taylor, G. (2014). Qatar allows money to flow to Islamic State, other terrorists'. The Washington Times - 10 December 2014.

Treagus, M., Cover, R. and Beasley, C. (2011) ASC's 'Integrity in Sport Literature Review, by Mandy Rob Cover Christine Beasley, Australian Sports Commission: Canberrra.

Trevino, L. and Nelson, K.: 2008, Managing Business Ethics (John Wiley, London).

Watson, N. (2011) Identity in Sport: A Psychological and Theological Analysis, in Parry, J., Nesti, M., and Watson, N. (eds.) Theology, Ethics and Transcendence in Sport (Routledge, London).

Williams, B.: 1973, 'Integrity', in J.J.C. Smart and B. Williams (eds.), Utilitarianism: For and Against (Cambridge University Press, New York) 108-117.

Zeidan, O. and Fauser, S. (2015) 'Corporate governance and corporate social responsibility in FIFA', Problems and Perspectives in Management, Volume 13, Issue 2. 
